\title{
Statutory Allocation and Budget Implementation in Southwest Nigeria
}

\author{
Festus Oladipupo Olaoye, Toyin Bankole \\ Department of Accounting, Ekiti State University, Ado-Ekiti, Ekiti State, Nigeria \\ Email: oladipupo.olaoye@eksu.edu.ng, olajumoke.fagbuagun@gmail.com
}

How to cite this paper: Olaoye, F.O. and Bankole, T. (2019) Statutory Allocation and Budget Implementation in Southwest Nigeria. Open Journal of Social Sciences, 7, 125-135.

https://doi.org/10.4236/jss.2019.77012

Received: March 24, 2019

Accepted: July 20, 2019

Published: July 23, 2019

Copyright (อ 2019 by author(s) and Scientific Research Publishing Inc. This work is licensed under the Creative Commons Attribution International License (CC BY 4.0).

http://creativecommons.org/licenses/by/4.0/

(c) (i) Open Access

\begin{abstract}
This study examined statutory allocation and budget implementation in $\mathrm{Ni}$ geria. This study covered all the six states of southwest geopolitical zone of Nigeria including Lagos State, Ogun State, Oyo State, Osun State, Ondo State and Ekiti State, over the period of 10 years spanning from 2008 to 2017. Data used in the study were collected from National Bureau of Statistics, Office of the Accountant General of the Federation, and annual budget of the selected states. The study made use of static panel estimation techniques such as pooled OLS estimator, fixed effect estimator and random effect generalized least square estimator, as well as Dumitrescu-Hurlin panel based granger causality test. Result showed that statutory allocation exerts insignificant, positive impact on actual expenditure to the tune of 0.109719 ( $\mathrm{p}=0.000<$ 0.05), and that there is no existence of causal relationship between statutory allocation and actual expenditure of southwest states in Nigeria. The study thus established that though impact of statutory allocation on actual expenditure is positive, such impact is not significant in the context of southwest states, and that past period statutory allocation to southwest states does not significantly depict the level of budget implementation in the current period. In addition, this study established among other things that there is heterogeneity effect across southwest states in the discourse of statutory allocation and budget implementation. Thus the study underscores the place of states uniqueness in the matter of budget implementation. Hence state government especially in the southwest geopolitical zone should device budget implementation plan based on the reality, their revenue generating capacity, without much dependence on federal government allocation in other to improve the effectiveness and efficient of revenue mobilization and disbursement for project execution and state management for each fiscal year.
\end{abstract}

\section{Keywords}

Statutory Allocation, Budget, Budget Implementation, Southwest Nigeria 


\section{Introduction}

The subject of statutory allocation is an intricate part of budget implementation of state especially in a country where fiscal federalism forms the basis for national resources mobilization and disbursement. The role played by statutory allocation in the discourse of state management has become a contentious issue of debate in recent time [1]. According to [2], statutory allocation to states in Nigeria is the major source of fund upon which the fundamentals of budget and viability for implementation are hinged. Among other reasons for state's high dependence on statutory allocation for budget implementation, especially in the context of developing country like Nigeria is the reality of low internal revenue generating capacity of most of the states [3]. Issues surrounding revenue allocation from the federal government to states' quarters had a checkered history in Nigeria, with plethora of commission and committee put-up at different times in the country to harmonize the structure and framework for revenue mobilization and allocation within tiers of government, all in the quest to improve the level of government through effective and efficient budget implementation [1].

The level of budget implementation in most southwest states is far from being satisfactory both in terms of recurrent expenditure and capital expenditure. For instance, the level of expenditure implementation in Ekiti stood at 73\% in 2011, $89 \%$ in 2013 [4]. In 2015 expenditure implementation only stood at 73\% [5], while in 2016 it was reported that expenditure implementation stood at $89 \%$ [6]. Budget implementation performance reported for Oyo state stood $67 \%, 96 \%$, and $90 \%$ for 2014, 2015, 2016 respectively [7]. In recent past some studies had been conducted on the subject of statutory allocation especially as it related to state management and budget implementation for instance [8] studies beyond statutory allocation, with focus on the contribution of internally generated revenue in Benue State: [1] assessed state governors and revenue allocation formula in Nigeria; [2] examined federal government statutory fund allocation to state in Nigeria; while [9] overviewed Nigerian federalism and the statutory allocation of fund. Observably, there was no objective analysis carried out in any of the previous studies to track the influence of actual statutory allocation on actual government expenditure implementation in southwest states in Nigeria. Hence this study examined the connection between statutory allocation and budget implementation in southwest states in Nigeria by analyzing the:

1) Impact of actual statutory allocation on actual expenditure of southwest states in Nigeria;

2) Causal relationship between actual statutory allocation and actual expenditure of southwest states in Nigeria.

\section{Literature Review}

\subsection{Statutory Allocation}

This is the allocation from the federal government that goes to each state as a means of revenue assistance from Federal Government. This allocation is some- 
times based on some criteria such as population of the state, availability of natural resources and the need for infrastructural development in the state. Statutory allocation is the amount standing to the credit pf the Federation account less the sum equivalent to 13 percent of the revenue accruing to the federation account directly from any natural resources as a first line charge for distribution to the beneficiaries of the derivation funds. Statutory allocation to state is based on the sharing of the federation account in which $56 \%$ goes to the federal government, $24 \%$ to the state government and $20 \%$ to local government [10].

\subsection{Budget Implementation}

Budget implementation entails the execution of budget based on the key assumptions and benchmark that defines the budget structure. According to [11] Onyekpere (2018), budget implementation is a phase of the budget process where approval for fund release is always associated to the adequacy of fund generated within that fiscal year. According to [12], budget implementation requires close adherence to the dictate of the budget which depicts what economic and non-economic activities a government wants to undertake with special focus on policies, objectives and strategies for accomplishment that are substantiated with revenue and expenditure projection. Budget implementation according to [13] Smith and Thomas (2004) depict the objective accomplishment of program related to objectives and goals within a definite time period as defined in the budget framework.

\subsection{Empirical Review}

[2], investigated federal government statutory fund allocation to states in Nigeria, using regression estimation techniques. Result showed that statutory allocation (SA) and internally generated revenue (IGR) jointly having a positive correlation with Gross Domestic Product. However, despite the huge natural endowment of Ekiti State, only Statutory Allocation had a significant positive effect on Gross Domestic Product.

[1], carried out an investigation on state government revenue allocation formula in Nigeria using the fourth republican system as a case of study. pros and cons of a new revenue were examined, the desperation for increased revenue from the government was also check mated. The study was carried out under a discursive research method and it was concluded positing that the litany of poor socio economic amenities, like health care, educational facilities and potable water, months of unpaid salaries are common features hidden by boastful talk and deceptive propaganda should be used as indices for denying the states any additional revenue.

[14], examined the equitable budgetary allocation as a catalyst for achieving national development in Nigeria the study made use of discursive research method. It was found in the study that skewed budgetary allocation causes imbalance development which in turn may result into an underdevelopment in the northern part on the country. it was concluded in the study that to achieve holis- 
tic national development in Nigeria, resources must be equitably distributed.

[15], focused on budgetary preparation implementation in the Nigerian public sector. The study made use of discursive research approach. It was established in the study proper public procurement philosophy will engender a strong legal, organizational and professional framework to make budgeting and budget implementation in the Nigerian Public Sector robust and effective.

[9], investigated into the Nigerian federalism and the statutory allocation of funds. The study explained some concepts which germane to the discourse of the study such as the concept of federalism in Nigeria, meaning and evolution of local government functions of local government council as well as the structure and control of funds of local government council. It was concluded that local government in terms of finance is expected to be independent of state government in a true federalism in such a way that state influence on the third tier could be avoided. It was therefore suggested that local council should be constituted by elective representatives of the people and it consists of Chairman of the council, Vice Chairman and Councilors.

[3], examined the growth evidence of federal government allocation share in Nigeria. The study employed the dynamic model and correlation analysis. Aggregate data used were generated from the central bank of Nigeria, Annual statistical bulletin. The scope of the study covered the period 39 years spanning from 1970 through 2009. Result of the analysis conducted in the study revealed that at $5 \%$ level of significance, the allocation to the federal government, allocation to the state government and state government internally generated revenue significantly impact growth, while allocation to the federal government and state government exert negative impact on growth.

[8] carried out a critical evaluation of the contribution of personal income tax on internally generated revenue of Benue state. The study utilized secondary data sources of data generated from the budget office of ministry of finance from 1999 to 2014. The data were analyzed using multiple regression model. Result of the analysis showed that PIT contributes significantly to IGR of Benue state during the period under study and hence recommend that the state should improve on these various sources of revenue as it is a genuine source through which the government deficits finances can be solved.

[16], assessed the factors responsible for budget failure in Nigeria, in an attempt to establish thesis objective, the study specifically determined the budgetary role in the economic planning of Nigeria and examined the effectiveness of budgeting in special development of the nation. Secondary data sourced from the CBN publications and statistical bulletin and NBS publications were collated in the study. ANOVA was used in analyzing data sourced in the study. Discoveries ascertained in the study depicted that budgeting has a strong relationship with Nigerian GDP and a strong relationship was revealed between budgeting and poverty index. Following these findings, the study suggested that government should enact an enabling law that will ensure the workability of its budget according to its plans and increase the proportion of capital expenditure to re- 
current expenditure budget preparation should start in good time; more capital expenditure should be included in the budget plan to speed increase in the value of social development and money not accessed during the period of budget implementation could be moved to a more viable project.

[17], studied the effect of fiscal decentralization and revenue allocation on local government performance in Nigeria. The study elucidated that the Nigerian state is politically structure into three governmental tiers. The study therefore examined if there is a nexus between local government failure and the nature of fiscal decentralization and revenue allocation in Nigeria. The study presented key issues, trend and challenges in the operation of fiscal decentralization in Nigeria. it was concluded that local governments in Nigeria are not viable; because constitutionally, they are confined to non-viable sources of sustenance in addition to the problematic fiscal jurisdiction that exists between them and states government; which impoverish the local government and become a constrain to its service delivery capacity in rural areas.

[18], examined budget as an instrument of realizing the goal of public policy Using data generated from secondary sources, it was found that the goals of most policies were not accomplished in Nigeria due to incessant budget failure at the stage of the formulation and implementation. Consequently, the paper suggested the way forward which includes; effective monitoring, timely submission of the budget to legislature by the presidency, discouragement of unnecessary lobbying of National Assembly by MDAs and avoidance of temptations of allocating huge amount to new projects while the on-going projects are starved of funds.

\section{Research Method}

\subsection{Model Specification}

This study made use of a single equation modeling in which budget implementation measured in terms actual expenditure was specified as a function of statutory allocation (STA), alongside internally generated revenue as control variable. The model used in this study is a adapted version of the model used by [2], which specified gross domestic product (GDP) as a function of statutory allocation and internally generated revenue (IGR), the adapted model is presented in Equation (1)

$$
Y_{i t}=\alpha_{0}+\alpha_{1} \mathrm{STA}_{i t}+\alpha_{2} \mathrm{IGR}_{i t}+\mu_{i t}
$$

The new version of the above model replaced gross domestic product with measure of budget implementation as presented in functional and linear forms below

$$
\begin{gathered}
\mathrm{AE}=f(\mathrm{STA}, \mathrm{IGR}) \\
\mathrm{AE}_{i t}=\alpha_{0}+\alpha_{1} \mathrm{STA}_{i t}+\alpha_{2} \mathrm{IGR}_{i t}+\mu_{i t}
\end{gathered}
$$

\subsection{Scope and Source of Data}

This study covered all the six states of southwest geopolitical zone of Nigeria in- 
cluding Lagos State, Ogun State, Oyo State, Osun State, Ondo State and Ekiti State, over the period of 10 years spanning from 2008 to 2017. Data used in the study were collected from National Bureau of Statistics, Office of the Accountant General of the federation, and Annual budget of the selected states.

\subsection{Method of Analysis}

This study made use of static panel estimation techniques such as pooled OLS estimator, fixed effect estimator and random effect generalized least square estimator. The static estimators were evaluated using post estimation test such as restricted F-test (to compare pooled OLS estimation result with the fixed effect estimation result for heterogeneity effect validation across sampled state, and over the period covered in the study) and Hausman test (to compare fixed effect estimation result with random effect estimation result in the quest to ascertain the most consistent and efficient estimation result). Causal relationship between actual statutory allocation and actual expenditure was analyzed with the use of Dumitrescu-Hurlin panel based granger causality test.

\section{Data Analysis and Result}

This section presents results of analysis conducted in the study. Presented in this section include results of correlation analysis, pooled OLS analysis, fixed effect analysis, random effect analysis, as well as post estimation test results

\subsection{Correlation Analysis}

As shown in Table 1 there is positive correlation between actual expenditure and statutory allocation which connote that for the period covered in the study actual expenditure of southwest state move predominantly in the same direction with statutory allocation, and that the correlation is averagely strong at reported correlations statistics of 0.5327 . Result also showed that there is a very strong correlation between internally generated revenue and actual expenditure of southwest states in Nigeria between 2008 and 2017, given the reported correlation statistics of 0.9813 . In addition result established existence of averagely strong positive correlation between internally generated revenue and statutory allocation of southwest states.

\subsection{Pooled OLS Estimation}

As shown in Table 2 pooled OLS estimation result revealed that when heterogeneity

Table 1. Correlation matrix.

\begin{tabular}{cccc}
\hline & AE & STA & IGR \\
\hline AE & 1.0000 & & \\
STA & 0.5327 & 1.0000 & \\
IGR & 0.9813 & 0.5282 & 1.0000
\end{tabular}

Sources: Author's Computation, (2019). 
Table 2. Pooled OLS parameter estimates.

\begin{tabular}{ccccc}
\hline Variable & Coefficient & Standard Error & T-Test Values & Probability \\
\hline C & 46.82036 & 6.931485 & 6.75 & 0.000 \\
STA & 0.1013295 & 0.1516894 & 0.67 & 0.507 \\
IGR & 1.707277 & 0.0526464 & 32.43 & 0.000 \\
\hline
\end{tabular}

R-square $=0.9632 ;$ Adjusted R-square $=0.9619 ;$ F-statistics $=745.46 ; \operatorname{Prob}(F-$ stat $)=0.0000$.

across southwest states in Nigeria is not incorporated into the model, statutory allocation exert insignificant positive impact on actual expenditure, to the tune of 0.1013295 ( $\mathrm{p}=0.507>0.05)$ reported R-square stood at 0.9632 , thus reflecting the capacity of statutory allocation and internally generated revenue of southwest states to explain about $96 \%$ of the systematic variation in actual expenditure.

\subsection{Fixed Effect Panel Analysis}

As shown in Table 3, fixed effect estimation result revealed that when heterogeneity effect across southwest states was incorporated into the model as intercept term, result as presented in Table 3 showed that statutory allocation exerts positive but insignificant impact on actual expenditure with coefficient estimate of 0.1281688 ( $p=0.352>0.05)$. Result also showed that when heterogeneity effect across period covered in the study was incorporated into the model as intercept term, the impact of statutory allocation remains positive and significant 0.0022463 ( $\mathrm{p}=0.990>0.05$ ). Reported R-square statistics stood at 0.9747 and 0.9691 for cross-sectional and period effect estimations respectively, thus reflecting that about $97 \%$ and $97 \%$ of the systematic variation in actual expenditure of southwest states can be explained by statutory allocation and internally generated revenue when heterogeneity across the states and over time was incorporated into the model as intercept term.

\subsection{Random Effect Analysis}

As shown in Table 4 random effect estimation reflects the impact of statutory allocation on actual expenditure, when heterogeneity effect across states and over time was subsumed into the error term. In clear terms result showed that statutory allocation exert insignificant positive impact on actual expenditure to the tune of 0.109719 ( $\mathrm{p}=0.000<0.05)$. Reported R-square statistics stood at 0.9632 , which connote that about $96 \%$ of the systematic variation in actual expenditure of southwest states can be explained by statutory allocation and internally generated revenue.

\subsection{Post Estimation Test}

As shown in Table $5 \mathrm{f}$-statistics values of 4.75 and 1.02 with probability values of 0.0012 , and 0.4397 for cross sectional and period specific effect revealed that there is enough evidence to reject the null hypothesis that all differential intercept 
Table 3. Fixed effects estimates (Cross-Sectional and Period Specific).

\begin{tabular}{|c|c|c|c|c|c|}
\hline \multicolumn{3}{|c|}{ CROSS-SECTIONAL SPECIFIC EFFECT } & \multicolumn{3}{|c|}{ TIME SPECIFIC EFFECT } \\
\hline Variables & Coefficients & Prob & Variables & Coefficients & Prob \\
\hline $\mathrm{C}$ & 127.7877 & 0.000 & $\mathrm{C}$ & 24.58784 & 0.060 \\
\hline STA & 0.1281688 & 0.352 & STA & 0.0022463 & 0.990 \\
\hline IGR & 1.380541 & 0.000 & IGR & 1.709912 & 0.000 \\
\hline Effects & & & Effects & & \\
\hline Ogun State & -95.55128 & 0.001 & 2009 & 11.03268 & 0.531 \\
\hline Oyo State & -63.27248 & 0.031 & 2010 & 20.66339 & 0.233 \\
\hline Osun State & -62.67727 & 0.040 & 2011 & 25.84719 & 0.138 \\
\hline Ondo State & -85.92425 & 0.006 & 2012 & 31.43288 & 0.095 \\
\hline \multirow[t]{5}{*}{ Ekiti State } & -88.25731 & 0.005 & 2013 & 33.03869 & 0.083 \\
\hline & & & 2014 & 36.81312 & 0.046 \\
\hline & & & 2015 & 40.27401 & 0.024 \\
\hline & & & 2016 & 33.05381 & 0.061 \\
\hline & & & 2017 & 32.71452 & 0.064 \\
\hline \multicolumn{3}{|c|}{ R-square $=0.9747$} & \multicolumn{3}{|c|}{ R-square $=0.9691$} \\
\hline \multicolumn{3}{|c|}{ Adjusted R-square $=0.9713$} & \multicolumn{3}{|c|}{ Adjusted R-square $=0.9620$} \\
\hline \multicolumn{3}{|c|}{ F-statistics $=286.47$} & \multicolumn{3}{|c|}{ F-statistics $=136.75$} \\
\hline \multicolumn{3}{|c|}{$\operatorname{Prob}(\mathrm{F}-\mathrm{stat})=0.0000$} & \multicolumn{3}{|c|}{$\operatorname{Prob}($ F-stat $)=0.0000$} \\
\hline
\end{tabular}

Sources: Author's Computation, (2019).

Table 4. Random effect estimation.

\begin{tabular}{ccccc}
\hline Variable & Coefficient & Standard Error & Z-Test Values & Probability \\
\hline C & 51.36311 & 10.024 & 5.12 & 0.000 \\
STA & 0.109719 & 0.1391975 & 0.79 & 0.431 \\
IGR & 1.608215 & 0.0822179 & 19.56 & 0.000 \\
\hline
\end{tabular}

R-square $=0.9632$, Wald chi2 $(5)=445.59$, Prob $>$ chi2 $=0.0000$. Source: Authors' Computation (2019).

Table 5. Restricted F test of heterogeneity (Cross-Sectional and Time Specific).

\begin{tabular}{ccc}
\hline & F-statistics & Probability \\
\hline Cross sectional & 4.75 & 0.0012 \\
Time specific & 1.02 & 0.4397 \\
\hline
\end{tabular}

Source: Author's Computation, (2019).

corresponding to the cross sectional specific units are equal to zero, but otherwise for the period specific intercepts. Hence this validated that there is cross sectional heterogeneity/uniqueness effect amidst southwest states in the discourse of statutory allocation and budget implementation.

As shown in Table 6 chi-square statistics of 5.45 alongside probability value of 0.0654 reflect that there is no enough evidence to reject the null hypothesis that 
Table 6. Hausman test.

\begin{tabular}{ccc}
\hline Null hypothesis & Chi-square stat & Probability \\
\hline Difference in coefficient not systematic & 5.45 & 0.0654 \\
\hline
\end{tabular}

Source: Author's Computation, (2019).

differences in coefficients of fixed effect estimator and random effect estimation is not significant. Thus random effect estimation presented in Table 4 is the most consistence and efficient estimation result for the study.

\subsection{Causal Relationship Analysis}

As shown in Table 7 result of pairwise Dumistrescue-Hurlin panel causality test conducted in the study revealed that there is no existence of causal relationship between statutory allocation and actual expenditure of southwest states in Nigeria, given the reported probability values of 0.6673 and 0.3664 corresponding to the $\mathrm{W}$-stat and Zbar-stat for the null hypotheses raised in the study.

\section{Discussion}

The study established first that, there is a mildly strong correlation between statutory allocation and actual expenditure of southwest states in Nigeria, which connote that rising (or falling) statutory allocation is happening fairly synchronously as rising (of falling) government actual expenditure. Secondly estimation result presented in Table 4 being the most consistent and efficient estimator established that statutory allocation exerts positive but insignificant impact on the level of budget implementation measured in terms of actual expenditure. More specifically result showed that one billion naira increase in statutory allocation will in the same period result in increase in actual expenditure by about 0.109719 billion naira (i.e. 109,719,000 naira), which is consider not significant. Thirdly, result showed that there is no granger causality running from statutory allocation or vice versa, which implies that previous statutory allocation to southwest state does not significantly influence the level budget implementation in the current period and vice versa.

\section{Conclusion and Recommendation}

This study established that though the impact of statutory allocation on actual expenditure is positive, such impact is not significant in the context of southwest states, hence the study underscores that higher statutory allocation to southwest state might not culminate into significant improvement in the level of budget implementation. This study also established that past period statutory allocation to southwest states does not significantly depict the level of budget implementation in the current period. In addition, this study established among other things that there is heterogeneity effect across southwest states in the discourse of statutory allocation and budget implementation. Thus, the study underscores the place of states uniqueness in the matter of budget implementation. Hence state 
Table 7. Dumitrescu-Hurlin panel causality test result.

\begin{tabular}{cccc}
\hline Null hypothesis & W-Stat & Zbar-Stat & Probability \\
\hline STA does not homogeneously cause AE & 0.7518 & -0.4298 & 0.6673 \\
AE does not homogeneously cause STA & 1.5215 & 0.9033 & 0.3664 \\
\hline
\end{tabular}

Note: *connote rejection of the null hypothesis at $5 \%$ significance level. SOURCE: Author's Computation, (2019).

government especially in the southwest geopolitical zone should device budget implementation plan based on the reality their revenue generating capacity, without much dependence on federal government allocation in other to improve the effectiveness and efficiency of revenue mobilization and disbursement for project execution and state management for each fiscal year.

\section{Conflicts of Interest}

The authors declare no conflicts of interest regarding the publication of this paper.

\section{References}

[1] Onuigbo, R.A and Eme, O.I (2015) State Governors and Revenue Allocation Formula in Nigeria: A Case of the Fourth Republic. International Journal of Accounting Research, 2, 14-36. https://doi.org/10.12816/0017348

[2] Olowolaju, P.S., Ajibola, O., Ishola, R.A. and Falayi, I. (2014) Federal Government Statutory Fund Allocation to States in Nigeria, West Africa: Any Reasonable Story to Tell? American International Journal of Social Science, 3, 152-164.

[3] Ojide, M.G. and Ogbodo, J.C. (2015) Fiscal Federalism in Nigeria: Implication for Growth. British Journal of Economics, Management \& Trade, 5, 442-449. https://doi.org/10.9734/BJEMT/2015/5859

[4] Fayemi, K. (2014) Budget of Stability and Growth. https://www.premiumtimesng.com/news/151260-governor-fayemi-presents-n103-b illion-budget-ekiti-assembly.html

[5] Ekiti State Bureau of ICT (2017) Ekiti State Governor, Ayodele Fayose Presents 2016 Budget to The State House of Assembly. https://guardian.ng/news/fayose-presents-n67b-budget-to-assembly/

[6] Olayinka, L. (2017) Gov Ayodele Fayose Present 2017 Budget to Ekiti State House of Assembly.

https://www.thenigerianvoice.com/news/239172/gov-ayodele-fayose-present-2017budget-to-ekiti-state-house.html

[7] Ministry of Finance and Budget, Oyo State (2017) Oyo State Budget Performance from 2011 Till March 2017.

https://oyostate.gov.ng/ministry-of-finance-and-budget/\#1502897452263-8e0afd49$\underline{20 \mathrm{~b} 1}$

[8] Igyo, A.J., Simon, J. and Iorlumun, A.P.I. (2016) Beyond Statutory Federal Allocation: A Critical Evaluation of the Contribution of Personal Income Tax on Internally Generated Revenue of Benue State. British Journal of Economics, Management \& Trade, 13, 1-13. https://doi.org/10.9734/BJEMT/2016/24567

[9] Haruna, A.L. and Goni, U.A. (2013) Nigerian Federalism and the Statutory Alloca- 
tion of Funds: Analytical Review of Local Government as Third Tier of Government. IOSR Journal of Humanities and Social Science, 11, 1-9.

https://doi.org/10.9790/0837-1160109

[10] Federation Account Allocation Committee (2002) Allocation of Revenue (federation Account ETC) ACT.

https://nlipw.com/allocation-revenue-federation-account-etc-act/

[11] Onyekpere, E. (2018) Where Are the Budget Implementation Reports. https://punchng.com/where-are-the-budget-implementation-reports/

[12] Samuel, C.U. and Wilfred, I.U. (2009) Problems and Prospects of Budgeting and Budget Implementation in Local Government System in Nigeria. African Journal of Business Management, 3, 837-846.

[13] Smith, R.W. and Thomas, D.L. (2004) Public Budgeting in America. Pearson, Upper Saddle River, NJ.

[14] Saifullahi, S.I. and Abubakar, M.A. (2013) Equitable Budgetary Allocation: A Catalyst for Achieving National Development of Nigeria. European Scientific Journal, 9 , 264-274.

[15] Lawyer. C.O. (2013) Budget Preparation and Implementation in the Nigerian Public Sector. Research Journal of Finance and Accounting, 4, 50-54.

[16] Adekunle, S.B. (2010) Assessment of Factors Responsible for Budget Failure in Nigeria.

[17] Madu, A.Y., Abbo, U. and Rohana, Y. (2014) Effect of Fiscal Decentralization and Revenue Allocation on Local Government Performance: The Nigerian Experience. Journal of Governance and Development, 10, 55-68.

[18] Eghe, E.V. and Chima, P. (2015) Budget and Implementation of Public Policy in Nigeria. British Journal of Economics, Management \& Trade, 10, 1-8.

https://doi.org/10.9734/BJEMT/2015/19707 